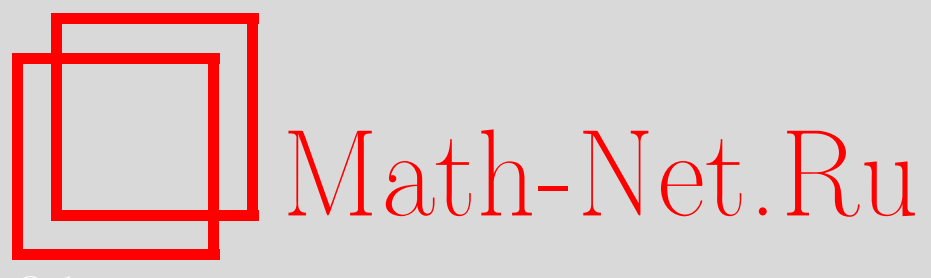

Г. С. Голицын, Р. А. Минлос, С. П. Новиков, В. М. Тихомиров, М. И. Фортус, Акива Моисеевич Яглом (некролог), УМН, 2008, том 63, выпуск 2, 153-156

DOI: https://doi.org/10.4213/rm9183

Использование Общероссийского математического портала Math-Net.Ru подразумевает, что вы прочитали и согласны с пользовательским соглашением http://www . mathnet.ru/rus/agreement

Параметры загрузки:

IP : 3.89 .197 .203

26 апреля 2023 г., 04:52:50

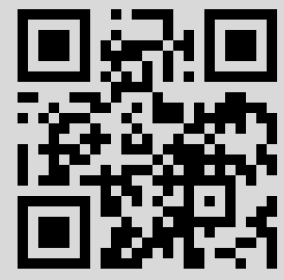




\section{Акива Моисеевич Яглом}

Не стало Акивы Моисеевича Яглома, крупного ученого с очень широким кругом интересов в математике и естествознании. И замечательного человека.

6 марта 1921 г. в Харькове в семье инженера родились братья-близнецы - Акива и Исаак. Братья были совершенно неразличимы и очень дружны.

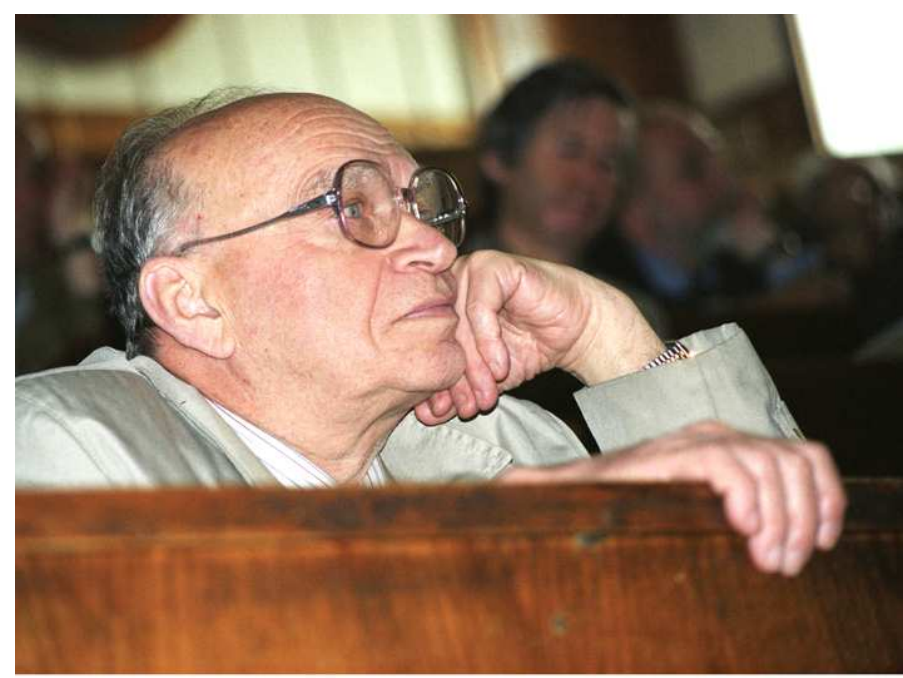

Когда мальчикам исполнилось шесть лет, семья переехала в Москву. В 1935/36 учебном году братья Ягломы стали заниматься в математических кружках при МГУ и слушать лекции для школьников, которые читали мехматские профессора. Вскоре братья стали заниматься в кружке Давида Оскаровича (Додика) Шклярского, человека, влюбленного в математику, и энтузиаста занятий со школьниками. Ему суждено было совершить переворот во всем кружково-олимпийском движении: вместо докладов он стал предлагать участникам своего кружка интересные задачи для решения. В 1938 г. такой стиль работы привел к триумфу: все первые премии были взяты участниками кружка Шклярского. Ими стали Владимир Волынский, Александр Кронрод и братья Ягломы. Премии победителям вручал Андрей Николаевич Колмогоров.

Окончив школу в том же году, А. М. Яглом поступает на физический факультет Московского университета, а его брат - на механико-математический. При этом они договорились, что оба будут учиться одновременно на обоих факультетах. Акива Яглом прекрасно учился: в 1940 г. в "Правде" была помещена фотография шести 
юношей с подписью: "Студенты физического факультета Московского государственного университета, досрочно закончившие зимнюю экзаменационную сессию на «отлично»", среди них А. М. Яглом. Братья Ягломы очень активно включились в культурную жизнь Москвы - театральную, музыкальную и художественную, они обрели очень широкий круг знакомых. В частности, оба тесно дружили с Андреем Сахаровым. К лету 1941 г. Акива Моисеевич окончил три курса и физфака и мехмата (тогда никаких специальных разрешений не требовалось: со своей физфаковской зачеткой он приходил на мехмат сдавать экзамены, и преподаватели проставляли оценку ему в зачетку). Началась война. Братья Ягломы не были призваны в армию из-за сильной близорукости. Они продолжали учиться сначала в МГУ, а затем в Свердловском университете (в Свердловск вместе с Народным комиссариатом черной металлургии, где работал отец, эвакуировалась семья Ягломов). В 1943 г. в Свердловск приехал Колмогоров. Братья Ягломы пришли на его лекцию. После лекции Колмогоров пригласил Ягломов в свой номер и долго беседовал с ними. Он ознакомил их с теорией турбулентности, которой активно занимался в то время. Летом 1942 г. братья Ягломы закончили Свердловский университет (в военные годы во многих высших учебных заведениях четвертый курс был последним). По рекомендации А.Н. Колмогорова оба брата поступили в на работу в Главную геофизическую обсерваторию, эвакуированную из Ленинграда в Свердловск.

В 1943 г. Колмогоров предложил Акиве Моисеевичу поступить к нему в аспирантуру в Математический институт им. В.А. Стеклова. Тот с радостью согласился. Колмогоров прислал Яглому вызов в Москву, и с осени того года А. М. был зачислен в аспирантуру МИАН. Одновременно началось его сотрудничество на кафедре теории вероятностей МГУ, возглавляемой Колмогоровым. Акива Моисеевич ожидал, что Колмогоров даст ему какую-нибудь тему по теории турбулентности, но он предложил ему развить на примере броуновского движения результаты своей работы по обратимости стохастических законов природы. А. М. Яглом в течение года справился с поставленной задачей, но в ответ на предложение Колмогорова организовать защиту и окончить аспирантуру попросил не реализовывать этот план, ибо хотел в течение двух оставшихся лет аспирантуры заниматься проблемами теоретической физики.

В 1946 г. состоялась защита кандидатской диссертации А. М. Яглома на тему "О статистической обратимости броуновского движения", и ему предстояло выбрать место работы. Его наиболее привлекало предложение И. Е. Тамма и В. Л. Гинзбурга поступить на работу в ФИАН, но А. М. отказался от этого предложения, узнав, что придется заниматься проблемами, связанными с атомным оружием. Из нескольких других возможностей Акива Моисеевич выбрал возглавляемую Колмогоровым лабораторию атмосферной турбулентности Института теоретической геофизики АН СССР. В лаборатории атмосферной турбулентности Акива Моисеевич проработал 45 лет (сначала в ИТГ, потом в ГЕОФИАНе и, наконец, в Институте физики атмосферы). С начала шестидесятых годов А. М. Яглом возглавил в ИФА лабораторию атмосферной турбулентности.

В начале своего творческого пути Акива Моисеевич, с одной стороны, развивал тематику А.Н. Колмогорова по теории случайных процессов, а с другой, сотрудничая с И. М. Гельфандом, занимался проблемами теоретической физики, связанными с теорией представлений и с континуальными интегралами. И почти сразу же он начал свои исследования по статистической гидродинамике. Первый цикл его работ включает публикации по теории марковских цепей, ветвящихся процессов, стохастической обратимости броуновского движения и статьи по экстраполяции и фильтрации случайных процессов, где А. М. значительно развил пионерские работы Колмогорова конца тридцатых - начала сороковых годов. Некоторые итоги его начальной деятельности по этой проблематике были подведены в его статье "Введение в теорию случайных функций", опубликованной в 1952 г. в "Успехах математических наук" и за- 
нимающей 165 страниц. В 1962 г. она была дважды издана в США как отдельная книга, так как ничего подобного там тогда еще не издавалось. В работах, совместных с И.М. Гельфандом и А.Н. Колмогоровым, развивалась теория информации. В 1955 г. А. М. Яглом защищает докторскую диссертацию под названием "Теория корреляции непрерывных процессов и полей с приложениями к задачам статистической экстраполяции временных рядов и к теории турбулентности."

В 1956 г. в Москве состоялся Третий Всесоюзный математический съезд. В трудах съезда помещены три доклада А. М. Яглома: "Количество информации и энтропия для непрерывных распределений” (с И. М. Гельфандом и А. Н. Колмогоровым), "Концептуальные интегралы" (с И. М. Гельфандом и Р. А. Минлосом) и "Микроструктура развитой турбулентности" (с А. М. Обуховым). В пятидесятые годы начинается цикл его популяризаторских публикаций, среди которых вышедшая в 1957 г. замечательная книга "Вероятность и информация", написанная с И. М. Ягломом.

В дальнейшем А. М. исследовал теоретические и прикладные проблемы турбулентности и геофизической гидродинамики. Среди работ начального периода прежде всего надо отметить его работу 1948 г. по теории однородной и изотропной турбулентности в вязкой сжимаемой жидкости и работу 1949 г. о поле ускорений в турбулентном потоке. Существенным результатом последней работы явилось обнаружение того, что частотный спектр лагранжевых ускорений жидкой частицы в турбулентном потоке является постоянной величиной, связанной со скоростью диссипации кинетической энергии турбулентности, т. е. это "белый шум" в инерционном интервале развитой турбулентности. Впоследствии это позволило связать представления теории турбулентности Колмогорова-Обухова с результатами теории броуновского движения. В другой работе того же года было выведено динамическое уравнение для поля температур пассивной примеси, что явилось вторым точным результатом в теории турбулентности после колмогоровского динамического уравнения для поля скоростей (его знаменитого закона "четырех пятых"). В 1965 г. вышла первая, а в 1967 г. вторая часть монографии А. С. Монина и А. М. Яглома "Статистическая гидродинамика" [1]. В 1971 и 1975 гг. оба тома вышли в английском переводе в издательстве MIT Press, расширенные и дополненные материалами, появившимися к тому времени. В конце 70-х годов книга была издана в четырех томах на японском языке. Эта книга заслуженно считается энциклопедией по данной тематике.

Потребности приложений теории турбулентности к проблемам гидродинамики атмосферы стимулировали обобщение и дальнейшее развитие теории случайных процессов и полей. Работы А. М. Яглома способствовали созданию математического аппарата, необходимого для превращения статистической гидродинамики в строгую физико-математическую дисциплину. Им были детально изучены процессы со стационарными приращениями произвольного порядка, статистически однородные и изотропные, а также локально изотропные скалярные и векторные случайные поля. Для каждого из этих классов дан и проанализирован общий вид соответствующих корреляционных функций, а также получены спектральные представления как корреляционных и структурных функций, так и самих процессов и полей и исследованы свойства их спектральных характеристик.

В своей работе А. М. Яглом умел связывать теоретические исследования с результатами, полученными авторами экспериментальных работ. Этим, в частности, объясняется его интерес к проблемам статистического оценивания. При этом высокий уровень математической строгости исследований сочетается с изложением полученных результатов в форме, доступной прикладнику. В своих работах Акива Моисеевич использовал колоссальный объем литературы: списки литературы в его статьях и книгах обычно содержат максимально возможное количество литературных ссылок, причем значительная часть относится к приложениям и содержит экспериментальные результаты. Именно поэтому его статьи, обзоры и монографии уже давно стали 
настольными книгами для специалистов всего мира, работающих в самых различных областях науки: метеорологии, океанологии, гидрологии, радиотехнике и др.

Всего в списке научных трудов А. М. Яглома свыше 150 статей и семь книг.

Следует отдельно сказать о его уникальной двухтомной монографии [2], написанной уже давно, но не потерявшей своего значения. К сожалению, специалисты в России с ней не знакомы, так как ему не удалось издать ее тогда в СССР. Эта монография и сейчас заслуживает издания в русском переводе.

Наконец, нельзя не сказать о выдающемся педагогическом таланте Акивы Моисеевича. Он в течение ряда лет был профессором кафедры теории вероятностей МГУ. Его лекции и доклады на различных научных конференциях были всегда содержательны и интересны.

В 1992 г. А. М. Яглом переехал в США. Это было вызвано во многом семейными причинами. В Америке он стал работать в Массачусетском технологическом институте. В 1988 г. А. М. Яглом получил премию Американского физического общества имени Отто Лапорта, а в 2007 г. Европейский союз наук о Земле присудил ему медаль Л.Ф. Ричардсона. Ему должны были вручить эту медаль в апреле 2008 г.

Работая в MIT, А. М. получил грант на написание труда по развитию статистической гидродинамики за последние тридцать с лишним лет, прошедших после выхода в свет английского издания его монографии с А. С. Мониным. Он поставил перед собой цель описать то необозримое море литературы, которое родилось в развитие четырех крохотных заметок в ДАН СССР, опубликованных его учителем А. Н. Колмогоровым в 1941 и 1942 гг. Он хорошо понимал, что эта цель неосуществима. Отвечая как-то на вопрос о том, когда он собирается закончить свою работу, Акива Моисеевич напомнил, что некогда в Америке проходил шумный процесс, на котором преступнику был вынесен приговор в три пожизненных срока плюс еще тридцать лет. "Вот этого мне бы, возможно, хватило", - с улыбкой заключил он. Еще предстоит донести до русского читателя то, что было проделано А. М. Ягломом в осуществление поставленной им перед собой задачи.

Акива Моисеевич Яглом был интересным и глубоким человеком, истинным знатоком истории, литературы, театра, живописи, прекрасным собеседником, любил путешествия, особенно в горах. Он был теснейшим, сокровенным образом связан с Россией, ее культурой, наукой и просвещением. У него здесь было множество друзей, к встрече с которыми он всегда стремился. Акива Моисеевич старался раз в год посещать Россию. Он посетил Москву и летом 2003 г. - он приехал на конференцию, посвященную столетию со дня рождения А. Н. Колмогорова, желая воздать уважение и благодарность великому математику и своему учителю. Он был добрым и участливым человеком. Его образ навсегда сохранится в сердцах тех, кому посчастливилось общаться с ним, а его труды долго будут востребованы в науке.

$$
\begin{array}{r}
\text { Г. С. Голицин, Р.А. Минлос, С.П. Новиков, } \\
\text { В.М. Тихомиров, М.И. Фортус }
\end{array}
$$

\section{Список литературы}

[1] А.С. Монин, А.М. Яглом, Статистическая гидромеханика, Наука, М., 1965; англ. пер.: A. S. Monin, A. M. Iaglom, Statistical fluid mechanics, MIT Press, Cambridge, MA, 1975.

[2] A. M. Yaglom, Correlation theory of stationary and related random functions. I: Basic results; II: Supplementary notes and references, Springer Ser. Statist., Springer, New York, 1987. 